\section{Olive Mill Wastewater for Bioethanol Production using Immobilised Cells}

\author{
K. Ayadi, ${ }^{{ }^{*}}$ M. Meziane, ${ }^{b}$ D. Rouam, ${ }^{\mathrm{b}}$ \\ M. N. Bouziane, ${ }^{b}$ and K. El-Miloudic \\ a Laboratoire Eau et Environnement, Faculté de Technologie, Université Hassiba Benbouali de \\ Chlef, Algérie \\ b Laboratoire Bio-Ressources Naturelles, Faculté des Sciences de la Nature et de la Vie, \\ Université Hassiba Benbouali de Chlef, Algérie \\ 'Laboratoire Physique Théorique et Physique des Matériaux, Faculté de Technologie, Université \\ Hassiba Benbouali de Chlef, Algérie
}

This work is licensed under a Creative Commons Attribution 4.0 International License

\begin{abstract}
Physicochemical and microbiological characteristics of a local traditional olive mill wastewater, at Ennakhla-Chlef in northern Algeria, were evaluated. The olive mill wastewater samples had slight acidity of $0.65 \%$ with a $\mathrm{pH}=4.88$, and electrical conductivity of $34 \mathrm{mS} \mathrm{cm}^{-1}$. The chemical oxygen demand (COD) and the biological oxygen demand (BOD $)_{5}$ reached up to $183 \mathrm{gl}^{-1}$ and $7 \mathrm{gl}^{-1}$, respectively. In addition, the samples showed $1.72 \mathrm{gl}^{-1}$ of total phenolic compounds. Preliminary microbiological analysis of the wastewater showed the presence of various microorganisms represented especially by lactic acid bacteria and Enterococcus sp. to the aim of this work was to investigate the possibility of using yeast strains isolated from olive mill wastewater in the fermentation of the latter. The results shown that fermentation with yeast can produce ethanol at an extent of $1.4 \%(\mathrm{v} / \mathrm{v})$. This can constitute a strategy for treating mentioned wastewater and transforming it into valuable biomolecules.
\end{abstract}

Keywords

Olive mill wastewater, physicochemical parameters, microbial composition, immobilised cells fermentation, bioethanol

\section{Introduction}

Many Mediterranean countries are facing the problem of eliminating effluents from the olive oil production industry. ${ }^{1,2}$ Olive mill wastewater (OMW) is highly polluting, heavily loaded with organic matter, and particularly affects the quality of the natural environment in which it is discharged. ${ }^{3}$ The high organic load of OMW requires a high oxygen consumption, expressed in terms of chemical oxygen demand (COD) and biological oxygen demand (BOD), leading to eutrophication of surface water. ${ }^{4} \mathrm{OMW}$ also reduces soil quality by increasing its water repellence due to the presence of aliphatic compounds in addition to the presence of polyphenols known for their phytotoxic effect preventing seed germination and plant growth. ${ }^{5,6}$

The literature shows a variety of approaches for the treatment of OMW before disposal in nature. ${ }^{1}$ The wide variety of components found in OMW requires different treatment technologies to eliminate pollutants with harmful effects on the environment. Various processes are applicable, such as biological, ${ }^{7}$ physicochemical, ${ }^{8}$ and heat treatments. ${ }^{9}$ Membrane filtration, electrochemical treatment, and osmotic distillation are also reported for the treatment of OMW, among other methods., ${ }^{8,10}$

Proper management of industrial, agricultural, and food residues should reduce their negative impact on the envi-

\footnotetext{
${ }^{*}$ Corresponding author: Dr Khadidja Ayadi

Email: k.ayadi@univ-chlef.dz
}

ronment. In the last decade, the valorisation of OMW has attracted much attention from research teams. It has been shown that an environmental issue could be turned into valuable products ${ }^{1}$ such as biofuel, ${ }^{11}$ bioactive and nutraceutical compounds, ${ }^{12}$ antibacterial and anti-inflammatory compounds, ${ }^{13}$ anti-oxidant compounds ${ }^{14}$ along with the common polyphenols. ${ }^{15,16}$

In the fermentation process of biofuel production, the use of cell immobilisation has many benefits. It avoids the washing effect of microorganisms, stabilises the $\mathrm{pH}$ of the medium, and prolongs microbial activity during continuous processes. Cellular immobilisation technology allows multiple uses of the cellular system and reduces the inhibitory effect of metabolic products. In addition, the undesirable competition between different microorganisms may be reduced after immobilisation and the synergistic effect would be favoured. ${ }^{17}$

The purpose of this study was to investigate the possibility of producing bioethanol from OMW fermented by immobilised cells. Granulated pozzolan or bovine bones were chosen as immobilisation supports because of their high porosity and surface roughness promoting cell adhesion, as well as availability and very low cost. The working microorganisms used in the fermentation process were yeast strains isolated and grown from the same OMW. The effectiveness of the proposed anaerobic fermentation was investigated in the light of bioethanol production. 


\section{Materials and methods}

\subsection{OMW sampling}

OMW samples were collected from a traditional mill at Ennakhla-Chlef locality in northern Algeria $\left(36^{\circ} 15^{\prime} 36^{\prime \prime} \mathrm{N}\right.$, $11^{\circ} 24>50 \gg \mathrm{E}$ ). The process of oil production is described as follows: olives are washed and separated from plant debris, then crushed to a fine paste and kneaded by adding water. The obtained olive paste is pressed in a hydraulic piston. The liquid phase is drained, and then olive oil is separated from water by simple decantation. All samples were collected between November and January during the olive harvesting period. Samples of freshly produced OMW were taken from the storage ponds using a dipper, placed into sterilised bottles, and kept at $4{ }^{\circ} \mathrm{C}$ until used for physicochemical characterisation. However, the microbiological analysis was carried out right after sampling.

\subsection{Physicochemical characterisation}

The physicochemical characterisation of three samples of each OMW stock was carried out according to AFNOR (French Standardization Association) standards as follows:

The $\mathrm{pH}$ and the conductivity of OMW were measured at ambient temperature by calibrated Hanna Instruments $\mathrm{pH}$ and conductivity-meters, respectively. The acidity (expressed as percentage of oleic acid) was evaluated by titrating $10 \mathrm{ml} \mathrm{OMW}$ with $0.1 \mathrm{M} \mathrm{NaOH}$ solution. The turbidity was evaluated by a Hanna Instruments turbidimeter. Dry matter was determined after desiccation of $25 \mathrm{ml}$ of OMW samples at $105^{\circ} \mathrm{C}$ and expressed in $\mathrm{gl}^{-1}$ of the initial volume of OMW. Suspended matter (SM) in a volume of OMW sample was determined by filtration through a $0.45 \mu \mathrm{m}$ pore membrane. The mass of the residue was weighed as the SM in $\mathrm{g} \mathrm{ml}^{-1}$. The COD value was determined by the dichromate method..$^{18}$ The biological oxygen demand was determined by a BOD-meter after incubating a dilute solution of OMW giving the amount of oxygen consumed by microorganisms for 5 days $\left(\mathrm{BOD}_{5}\right)$ at $20{ }^{\circ} \mathrm{C}$ in the dark. The other physicochemical parameters: orthophosphates, chlorides, nitrites, nitrates, calcium, magnesium, ammonium, sulphate contents were measured according to Rodier. ${ }^{18}$ The salinity expressed in $\mathrm{mgl}^{-1}$ of OMW was determined by a Hanna Instruments portable salinometer.

Total phenolic contents were determined according to the Folin-Ciocalteu method. ${ }^{19}$ An amount of $0.5 \mathrm{ml}$ of sample solution was added to $2.5 \mathrm{ml}$ of Folin-Ciocalteu reagent and diluted with distilled water $1: 10$, followed by the addition of $4 \mathrm{ml}$ of $\mathrm{Na}_{2} \mathrm{CO}_{3}$. The mixture was then incubated in a water bath at $45{ }^{\circ} \mathrm{C}$ for $30 \mathrm{~min}$, and the absorbance was measured at $765 \mathrm{~nm}$ using a UV-Vis spectrophotometer against a blank sample. The total phenolic content was measured as gallic acid equivalents (mg GAE/g of extract). Residual oil and fats were determined using a partition-gravimetric method. A volume of OMW was acidified with $\mathrm{HCl}$ and mixed with hexane in a separating funnel. The organic layer was drained and then dried with $\mathrm{Na}_{2} \mathrm{SO}_{4}$. The solvent was recovered by distillation from a tared flask, and the remainder weighed as the quantity of oil and fats.

\subsection{Microbial composition determination}

The enumeration of the existing microorganisms was performed by the spread plate method. After homogenisation of the OMW samples, serial dilutions in sterile physiological water $(0.9 \% \mathrm{NaCl})$ were carried out from $10^{-1}$ to $10^{-6}$ dilution. An amount of $1 \mathrm{ml}$ of each dilution was placed in a Petri dish onto which was poured $20 \mathrm{ml}$ of agar medium previously autoclaved at $121^{\circ} \mathrm{C} / 15 \mathrm{~min}$ and cooled to $45{ }^{\circ} \mathrm{C}$. The dish was then homogenised by manual stirring and incubated in an oven. Only dishes with a colony number between 30 and 300 were retained for enumeration. The tests were repeated three times.

The microbiological composition was expressed as total aerobic and mesophilic flora (Plate Count Agar, incubated at $37{ }^{\circ} \mathrm{C}$ for $48 \mathrm{~h}$ ), total and faecal coliforms (VRBL Agar, incubated for $48 \mathrm{~h}$ at 37 and $44.5^{\circ} \mathrm{C}$, respectively), faecal streptococci (Rothe media presumptive test and Litsky media confirmatory test incubated at $37^{\circ} \mathrm{C}$ for 24 and $48 \mathrm{~h}$ ), yeasts and moulds (Potato-Dextrose Agar with chloramphenicol, incubated at $30^{\circ} \mathrm{C}$ for $72 \mathrm{~h}$ and 5-7 days, respectively), and lactic acid bacteria, especially Lactobacilli and Lactococci (MRS and M17 agar, incubated at $30{ }^{\circ} \mathrm{C}$ for 48-72 h, and the grown colonies were checked for Gram and catalase reactions before counting).

\subsection{Anaerobic fermentation}

\subsubsection{Microorganisms and culture conditions}

Dilutions in physiological water were made from OMW. An amount of $1 \mathrm{ml}$ of each dilution was spread on Oxytetracycline-Glucose-Yeast Extract Agar medium selective for yeasts in Petri dishes. After incubation at $25{ }^{\circ} \mathrm{C}$ for 5 to 7 days, the dishes exhibiting isolated colonies, which were easy to collect, were retained. At least 23 yeast strains were identified in OMW samples. The well-isolated colonies were stained with methylene blue, and then observed under a B-290 OPTIKA microscope to check the morphology and homogeneity of the cells. Morphological characteristics of cells and colonies including microscopic examination were used to isolate and purify the different strains. Using the API 20C AUX strip, all 23 isolates were identified as Saccharomyces cerevisiae strains. Each strain was purified by successive sub-culturing on agar Sabouraud, and stored at $4{ }^{\circ} \mathrm{C}$ until use.

\subsubsection{Carbon dioxide productivity}

This step was carried out to determine the best performing strain among the 23 isolated strains by measuring the volume of the produced $\mathrm{CO}_{2} \cdot{ }^{20}$ Fermentation of $45 \mathrm{ml}$ of sterilised OMW (compared to Sabouraud broth) in the presence of $4 \cdot 10^{5} \mathrm{CFU} / \mathrm{ml}$ isolated yeast strains was carried out in sterile glass tubes in anaerobic conditions for $180 \mathrm{~h}$. The gas production was monitored using $100^{\circ} \mathrm{ml}$ graduated syringes directly connected to the fermentation reactor. The gas pressure pushed the plunger of the syringe, making it possible to measure the volume of the produced gas. 


\subsubsection{Cell immobilisation}

In this study, pozzolan and bovine bones were used for cell immobilisation as supports because of their porous nature. Pozzolan from the carrier of Beni Saf, Tlemcen (Algeria) was washed several times with water to remove impurities and then high-temperature treated before use. Granulated pozzolan $6 \mathrm{~mm}$ in diameter was obtained by size reduction and sieving of the rocks. The particles were of $60 \pm 5 \%$ porosity and $1.029 \pm 0.001$ density. The bovine bones were collected from a local butchery. The soft tissues were removed and the bones were crushed into small pieces of $2-3 \mathrm{~cm}$. Deproteinisation was realized by immersion in $1 \mathrm{~N} \mathrm{NaOH}$ solution and then in $7 \%$ hydrogen peroxide. The bone pieces were boiled in water for $10 \mathrm{~h}$, washed under flowing water, and dried at $80{ }^{\circ} \mathrm{C}$ for $1 \mathrm{~h}$. The obtained material was sterilised in an autoclave before use. The particles were of $75 \pm 5 \%$ porosity and $1.01 \pm 0.005$ density.

The porous supports were placed separately in a nutritional solution containing the yeast strain at $4 \cdot 10^{5} \mathrm{CFU} / \mathrm{ml}$ concentration. The mixture was incubated at $30{ }^{\circ} \mathrm{C}$ for 36 to $72 \mathrm{~h}$ until the cells were fixed. Visual inspection and microscopy analysis (B-290 Optika) confirmed the biofilm formation.

\subsubsection{Experimental setup}

The batch fermentation was carried out in a homemade experimental setup consisting of a column made from food-grade polypropylene, $15 \mathrm{~cm}$ high and $5 \mathrm{~cm}$ in diameter, packed with immobilised cells on pozzolan or bovine bones. The experimental setup was sterilised by autoclaving at $120{ }^{\circ} \mathrm{C}$ for $20 \mathrm{~min}$, and anaerobic conditions were respected.

\subsubsection{Fermentation medium}

The OMW was diluted 10 times with distilled water to reduce the concentration of polyphenols. OMW was thermally pre-treated at $120{ }^{\circ} \mathrm{C}$ for $20 \mathrm{~min}$, adn then decanted and filtered on a $10^{\circ} \mu \mathrm{m}$ filter paper. To eliminate solids further, it was centrifuged at $4500 \mathrm{rpm}$ for $30 \mathrm{~min}$. Finally, the $\mathrm{pH}$ of OMW was adjusted to 6.5 (optimal initial $\mathrm{pH}$ ) with $0.1 \mathrm{M} \mathrm{NaOH}$ solution.

\subsubsection{Bioethanol content analysis}

The determination of bioethanol content in the fermentation solution was carried out by permanganometry. However, a distillation step was necessary to separate ethanol and to avoid the titration of other compounds. The bioethanol thus collected was reacted with a $0.1 \mathrm{M}$ permanganate solution in the presence of $1 \mathrm{M}$ sulfuric acid. Back titration with $0.1 \mathrm{M}$ oxalic acid of the permanganate solution permitted the determination of the bioethanol content.

\section{Results and discussion}

The overall measurement results showed that OMW had a highly polluted discharge in the form of residual liquid. Its composition depends on the type of olives, the degree of their ripening (depending on the collection period), the cultivation system, the salting practice for preserving olives, climatic conditions, and the process used for the extraction of olive oil. ${ }^{21}$

\subsection{Physicochemical characteristics of the OMW samples}

Organoleptic characterisation showed that OMW samples were generally a dark brown to intense black effluent with a troubled appearance, smooth texture, and fresh taste of olive oil to annoying rancid odour.

Table 1 presents the physicochemical characteristics of the OMW samples. All the data were averaged over at least three measurements.

Table 1 - Physicochemical characteristics of OMW samples

\begin{tabular}{|c|c|c|c|}
\hline Characteristics & Value & Characteristics & Value \\
\hline $\mathrm{pH}$ & 4.88 & nitrites $/ \mathrm{mgl}^{-1}$ & 2.08 \\
\hline acidity / \% & 0.65 & nitrates $/ \mathrm{mgl}^{-1}$ & 1.95 \\
\hline $\begin{array}{l}\text { electrical conductivity / } \\
\mathrm{mS} \mathrm{cm}^{-1}\end{array}$ & 34.00 & calcium / $\mathrm{mgl}^{-1}$ & 7.04 \\
\hline turbidity / NTU & 138.90 & magnesium / $\mathrm{mgl}^{-1}$ & 19.82 \\
\hline dry matter / $\mathrm{gl}^{-1}$ & 22.60 & ammonium $/ \mathrm{mgl}^{-1}$ & 1.55 \\
\hline suspended matter $/ \mathrm{gl}^{-1}$ & 0.39 & sulphate / $\mathrm{mgl}^{-1}$ & 1.49 \\
\hline $\mathrm{COD} / \mathrm{gl}^{-1}$ & 183.00 & salinity / mgl-1 & 1.50 \\
\hline $\mathrm{BOD}_{5} / \mathrm{gl}^{-1}$ & 7.00 & $\begin{array}{l}\text { total phenolic } \\
\text { contents } / \mathrm{g}^{-1}\end{array}$ & 1.72 \\
\hline $\begin{array}{l}\text { orthophosphates / } \\
\mathrm{mg} \mathrm{I}^{-1}\end{array}$ & 1.31 & $\begin{array}{l}\text { residual oil and fats } \\
\mid \mathrm{gl}^{-1}\end{array}$ & 0.16 \\
\hline chlorides / $\mathrm{gl}^{-1}$ & 3.90 & & \\
\hline
\end{tabular}

The measured $\mathrm{pH}$ value of 4.88 in this study was within the limits of 4.4-5.4 reported in the literature..$^{22-24}$ The increase in acidity of the OMW was due to several factors, such as the duration of the stay in the storage basins. ${ }^{25}$ This can be explained by auto-oxidation and polymerisation reactions, which transform phenolic alcohols into phenolic acids. These reactions are manifested by a change in the initial colouring of the OMW to dark black. Indeed, the OMW under study was characterised by a very dark colouring.

Electrical conductivity is closely related to the concentration of dissolved ionic substances (total dissolved solids) and to their nature. The results obtained in this study ( $34 \mathrm{mS} \mathrm{cm}^{-1}$ ) are comparable to those found in general literature. As salinity is related to electrical conductivity, ${ }^{26}$ this was indicative of the presence of a high content of mineral salts. 
The OMW understudy was slightly loaded with suspended matter. According to Table 1, turbidity and SM values were $138.9 \mathrm{NTU}$ and $0.385 \mathrm{gl}^{-1}$, respectively. The low values of turbidity and SM may be explained by the origin of the OMW sampling. The latter were sampled from storage tanks over an average duration of a few days, and the suspended matter decreased under the effect of settling.

The OMW was very rich in organic matter expressed in terms of chemical and biological oxygen demands. According to Table 1, the values of COD and $\mathrm{BOD}_{5}$ were 183 and $7 \mathrm{gl}^{-1}$, respectively. However, the very low $\mathrm{BOD}_{5} /$ COD ratio indicated a poor biodegradability of the OMW. When discharged without proper treatment, OMW causes organic pollution to water and soil, and asphyxiation of microorganisms. Most authors attribute this high toxicity to the presence of phenolic compounds. ${ }^{3-6}$

The content of phenolic compounds in OMW can reach up to $24 \mathrm{gl}^{-1} .27$ In our case, the value of $1.72 \mathrm{gl}^{-1}$ was lower than the value reported in the literature due to the origin of the OMW. The phenolic composition of the effluent depends on not only the variety, the maturity of the fruit, and the climatic conditions, but also on the technological processes used to separate the aqueous phase (OMW) from the oily phase.

Table 1 shows that the average chloride ion value was $3.9 \mathrm{gl}^{-1}$. The high chloride content was due to the practice of salting (adding salt in large quantities) to preserve the olives before the extraction process.

The residual fat content in OMW depends on the olive oil extraction system. The centrifugation process achieves low rates compared to the traditional process. Table 1 shows that the obtained fat content explains the viscous appearance linked to the presence of the oily fraction. It forms a lipid layer on the surface of the OMW at the level of the basins, which could limit natural evaporation.

\subsection{Microbial communities of OMW samples}

The microbiota of the olive mill wastewater is reported in Table 2. The standard plate count values for some samples were related to the environmental conditions of this liquid effluent.

Table 2 - Microbial communities identified in OMW samples

\begin{tabular}{l|c}
\hline Microbiota & Bacterial count (in $10^{4} \mathrm{CFU} / \mathrm{ml}$ ) \\
\hline total aerobic mesophilic flora & 0.55 \\
\hline total coliforms & 0 \\
\hline faecal coliforms & 0 \\
\hline faecal streptococci & 0 \\
\hline yeasts and moulds & 1.4 \\
\hline fungi & 10.8 \\
\hline lactic acid bacteria & 4.2 \\
\hline
\end{tabular}

Although OMW is not adequate for microorganism evolution, certain bacteria, yeasts, and fungi are resistant to acidic conditions as well as to the presence of phenolic compounds. ${ }^{23}$ Table 2 reveals the enumeration of microorganisms present in OMW understudy.

The obtained total aerobic mesophilic flora count is slightly lower than that reported in the literature. ${ }^{6,23}$ It is dependent on the extraction process, the adopted operating conditions, the region, and the storage conditions of the OMW, as well as on the physicochemical characteristics $(\mathrm{pH}$, phenolic compounds, mineral salts, heavy metals, fatty acids...).

Yeasts, moulds, and fungi can grow better than bacteria in $\mathrm{OMW}^{6,24}$ The tolerant power of the two groups is a genetic trait.

Lactic acid bacteria are also present in the OMW. The found value was $4.210^{3} \mathrm{CFU} / \mathrm{ml}$. Their presence was indicative of their resistance to the aggressive medium of OMW. ${ }^{23}$ However, their disappearance becomes normal over time due to the decrease in their resistance.

No faecal bacteria were detected in this study. The absence of these human pathogens was attributed to their sensitivity to low $\mathrm{pH}$ and the antibacterial activity of phenolics. Therefore, it can be stated that the studied OMW presented no sanitary or hygienic problem.

\subsection{Anaerobic fermentation of OMW}

Immobilised cells on pozzolan and bovine bones were selected for further studies by sieving under sterile conditions.

\subsubsection{Carbon dioxide productivity}

In this work, 23 yeast strains were isolated from OMW. However, the strains were differentiated by their carbon dioxide productivity. In the pre-selection procedure, it can be noted that the syringe piston raised very quickly in certain fermentation tubes but took a long time in others depending on the cells' bioactivity and the fermentation medium. Fig. 1 shows the gas productivity of the best four isolated strains comparing Sabouraud and OMW fermentation media.

In the Sabouraud medium, gas production increased to reach up to $615 \mathrm{ml} \mathrm{I}^{-1}$ on the third day and then decreased. On the other hand, the amount of produced gas in OMW was lower yet increasing even after five days. It can be concluded that yeast fermentation activity in Sabouraud was greater and faster than that in OMW. This was because Sabouraud was richer in glucose than OMW, which can be consumed directly by the yeast cells. However, the incubated strains have to first adapt to OMW, and then begin the biotransformation of the existing nutritional compounds in the medium..$^{28}$ The best yeast strain produced up to $175 \mathrm{mll}^{-1}$ on the fifth day of fermentation referring to Fig. 1. 

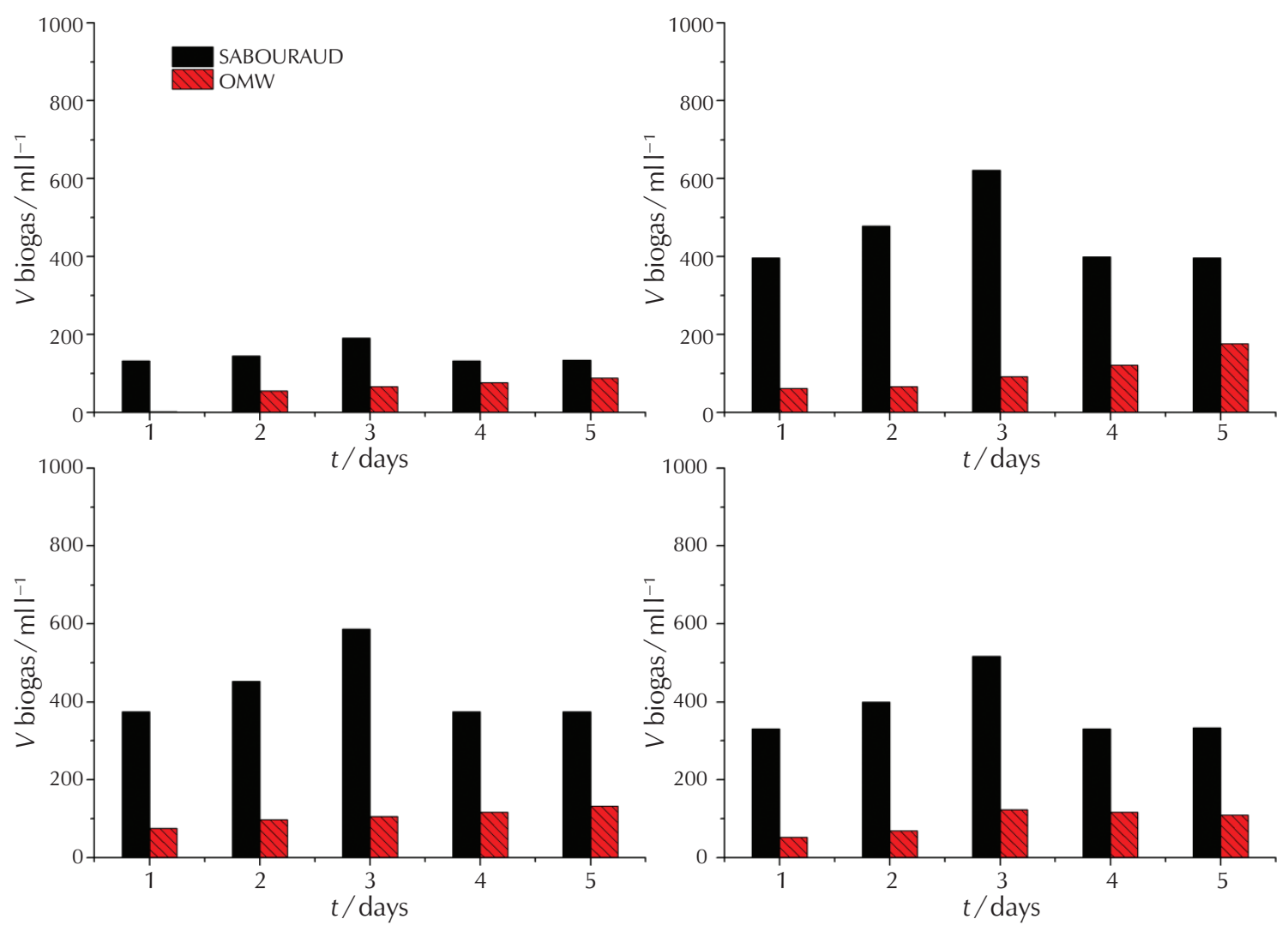

Fig. 1 - Carbon dioxide productivity of selected cells in Sabouraud and OMW fermentation media

\subsection{2 $\mathrm{pH}$ and ethanol}

In the last step, the yeast strain with the best fermentative activity was selected for further experiments regarding the production of bioethanol. Figs. 2 and 3 show the evolution of $\mathrm{pH}$ and ethanol productivity from OMW and Sabouraud using free, immobilised cells on pozzolan (IMC-POZZ) and immobilized cells on bovine bones (IMC-BONE).
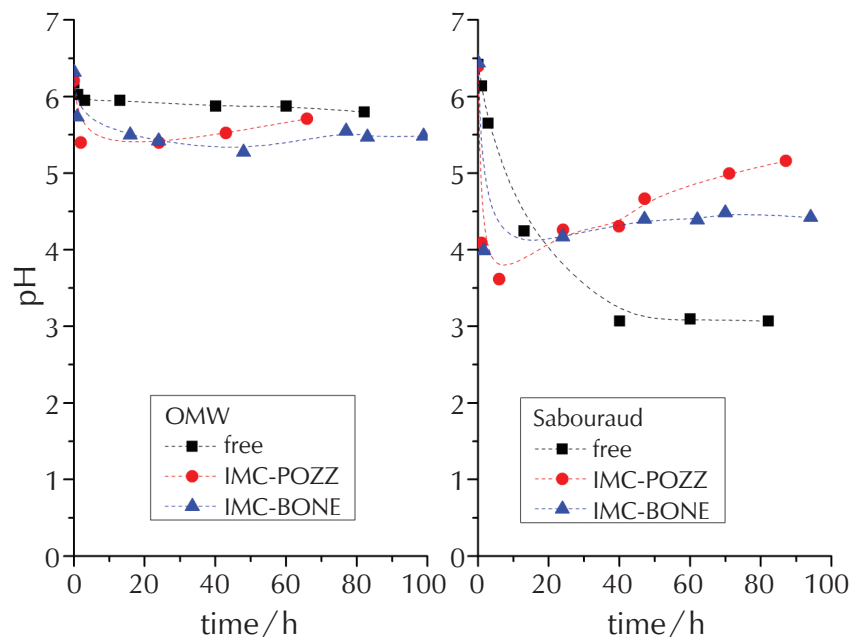

Fig. 2 - pH evolution during fermentation of free immobilised cells on pozzolan (IMC-POZZ), and immobilised cells on bovine bones (IMC-BONE)
In both cases, the $\mathrm{pH}$ decreased probably due to the production of pyruvic acid, the precursor of ethanol. ${ }^{29} \mathrm{Com}-$ paring the two fermentation media, the drop in $\mathrm{pH}$ was immediate and greater in Sabouraud than it was in OMW. This confirmed the observed behaviour indicated during the carbon dioxide production experiments.

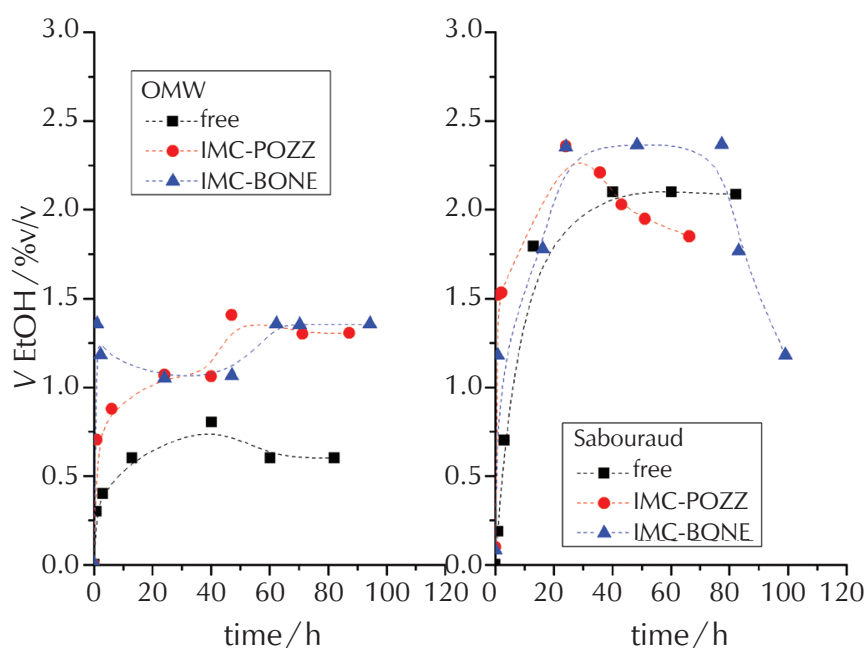

Fig. 3 - Ethanol (EtOH) productivity by fermentation of free immobilised cells on pozzolan (IMC-POZZ), and immobilised cells on bovine bones (IMC-BONE) 
In Sabouraud medium, ethanol was produced in measurable quantities within $1 \mathrm{~h}$ of fermentation, and reached maximum of up to 2 to $2.5 \%(\mathrm{v} / \mathrm{v})$ in about $20 \mathrm{~h}$. This was corroborated by the $\mathrm{pH}$ measurements. After a plateau, it was observed that ethanol productivity tended to decrease after the consumption of large quantities of glucose. On the other hand, ethanol productivity in OMW was lower due to unavailability of nutrients for the yeast cells contrary to Sabouraud medium. The plateau was reached within $40 \mathrm{~h}$ of fermentation with up to $1.4 \%(\mathrm{v} / \mathrm{v})$ of ethanol production.

In this study, the advantage of using yeast strains extracted from OMW was their assumed resistance to polyphenol toxicity. Zanichelli et al. demonstrated the inhibitory effect of polyphenols on the alcoholic fermentation of OMW. ${ }^{30}$ Furthermore, the OMW was diluted 10 times to reduce the polyphenol concentration. However, dilution also affected the concentration of carbon source needed by the microorganisms for conversion to bioethanol.

Comparison of bioethanol productivity of free vs. immobilised cells (Figs. 2 and 3) suggested that cell immobilisation enabled an increase in the productivity of ethanol from both OMW and Sabouraud. Slightly better performance was attributed to the cells immobilised on bovine bones. This was probably due to the higher cell density in the immobilisation support than free cells in the solution. In addition, bovine bones exhibit a higher porosity than pozzolan, providing additional sites for cell attachment leading to better productivity.

\section{Conclusion}

Wastewaters generated by the Ennakhla-Chlef Algeria olive mill were characterised. The physicochemical properties revealed a poor biodegradability of this effluent, suggesting its negative impact on soil and watercourses. However, the significant content of minerals and phenolics would permit the use of OMW as a source of valuable products. The microbiological characterisation identified the presence of lactic bacteria, which could be of practical relevance.

This study has shown that it is possible to produce bioethanol from OMW using Saccharomyces cerevisiae yeast strains previously isolated from OMW. Bioethanol was produced at an extent of $1.4 \%(\mathrm{v} / \mathrm{v})$ by anaerobic fermentation of OMW via immobilisation of the best performing yeast cells onto pozzolan and bovine bones. Further research is needed to optimise the fermentation conditions, such as dilution effect, inhibitory effect of polyphenols, nutritional supplement for the yeast cells, as well as competitive interference with other microorganisms.

\section{ACKNOWLEDGEMENTS}

The authors acknowledge the support of Prof. A. Ouagued, Dr. M. Kouidri, and Dr. B. Feraoun. The authors acknowledge the financial support of Direction Générale de la Recherche Scientifique et du Développement Technologique, Algeria.

\section{References \\ Literatura}

1. D. A. Sousa, A. I. Costa, M. R. Alexandre, J. V Prata, How an environmental issue could turn into useful high-valued products: The olive mill wastewater case, Sci. Total Environ. 647 (2019) 1097-1105, doi: https://doi.org/10.1016/j.scitotenv.2018.08.060.

2. J. M. Ochando-Pulido, J. R. Corpas-Martínez, J. A. Vellido-Perez, A. Martinez-Ferez, Optimization of polymeric nanofiltration performance for olive-oil-washing wastewater phenols recovery and reclamation, Sep. Purif. Technol. 236 (2020) 116261, doi: https://doi.org/10.1016/j.seppur.2019.116261.

3. S. Babić, O. Malev, M. Pflieger, A. T. Lebedev, D. M. Mazur, A. Kužić, R. Čož-Rakovac, P. Trebše, Toxicity evaluation of olive oil mill wastewater and its polar fraction using multiple whole-organism bioassays, Sci. Total Environ. 686 (2019) 903-914, doi: https://doi.org/10.1016/j.scitotenv.2019.06.046.

4. L. Bougarne, M. Ben Abbou, M. El Haji, H. Bouka, Consequences of surface water eutrophication: remedy and environmental interest, Mater. Today Proc. 13 (2019) 654-662, doi: https://doi.org/10.1016/j.matpr.2019.04.025.

5. F. Comino, V. Aranda, A. Domínguez-Vidal, M. J. Ayora-Cañada, Thermal destruction of organic waste hydrophobicity for agricultural soils application, J. Environ. Manage. 202 (2017) 94-105, doi: https://doi.org/10.1016/j.jenvman.2017.07.024.

6. A. Mekki, A. Aloui, Z. Guergueb, M. Braham, Agronomic Valorization of Olive Mill Wastewaters: Effects on Medicago sativa Growth and Soil Characteristics, Clean Soil Air Water. 46 (2018) 1800100, doi: https://doi.org/10.1002/ clen.201800100.

7. N. Dashti, N. Ali, M. Khanafer, H. Al-Awadhi, N. Sorkhoh, S. Radwan, Olive-pomace harbors bacteria with the potential for hydrocarbon-biodegradation, nitrogen-fixation and mercury-resistance: Promising material for waste-oil-bioremediation, J. Environ. Manage. 155 (2015) 49-57, doi: https:// doi.org/10.1016/j.jenvman.2015.03.010.

8. L. Ioannou-Ttofa, I. Michael-Kordatou, S. C. Fattas, A. Eusebio, B. Ribeiro, M. Rusan, A. R. B. Amer, S. Zuraiqi, M. Waismand, C. Linder, Z. Wiesman, J. Gilron, D. Fatta-Kassinos, Treatment efficiency and economic feasibility of biological oxidation, membrane filtration and separation processes, and advanced oxidation for the purification and valorization of olive mill wastewater, Water Res. 114 (2017) 1-13, doi: https://doi.org/10.1016/j.watres.2017.02.020.

9. C. Rocha, M. A. Soria, L. M. Madeira, Thermodynamic analysis of olive oil mill wastewater steam reforming, J. Energy Inst. 92 (2019) 1599-1609, doi: https://doi.org/10.1016/j. joei.2018.06.017.

10. A. Y. Gebreyohannes, E. Curcio, T. Poerio, R. Mazzei, G. Di Profio, E. Drioli, L. Giorno, Treatment of Olive Mill Wastewater by Forward Osmosis, Sep. Purif. Technol. 147 (2015) 292302, doi: https://doi.org/10.1016/j.seppur.2015.04.021.

11. M. Jeguirim, M.-L. M. L. Goddard, A. Tamosiunas, E. Berrich-Betouche, A. A. Azzaz, M. Praspaliauskas, S. Jellali, Olive mill wastewater: From a pollutant to green fuels, agricultural water source and bio-fertilizer. Biofuel production, Renew. Energy 149 (2020) 716-724, doi: https://doi.org/10.1016/j. renene.2019.12.079.

12. G. Ventura, C. D. Calvano, R. Abbattista, M. Bianco, C. De Ceglie, I. Losito, F. Palmisano, T. R. I. Cataldi, Characterization of bioactive and nutraceutical compounds occurring in olive oil processing wastes, Rapid Commun. Mass Spectrom. 33 
(2019) 1670-1681, doi: https://doi.org/10.1002/rcm.8514.

13. J. M. Silvan, M. A. Pinto-Bustillos, P. Vásquez-Ponce, M. Prodanov, A. J. Martinez-Rodriguez, Olive mill wastewater as a potential source of antibacterial and anti-inflammatory compounds against the food-borne pathogen Campylobacter, Innov. Food Sci. Emerg. Technol. 51 (2019) 177-185, doi: https://doi.org/10.1016/j.ifset.2018.05.013.

14. Z. Namazifar, F. Saadati, A. A. Miranbeigi, Synthesis, characterization and evaluation of antioxidant activity of tyrosol derivatives from olive mill wastewater, Chem. Pap. 73 (2019) 663-671, doi: https://doi.org/10.1007/s11696-018-0591-7.

15. N. Caporaso, D. Formisano, A. Genovese, Use of phenolic compounds from olive mill wastewater as valuable ingredients for functional foods, Crit. Rev. Food Sci. Nutr. 58 (2018) 2829-2841, doi: https://doi.org/10.1080/10408398.2017.1 343797.

16. M. Mattonai, A. Vinci, I. Degano, E. Ribechini, M. Franceschi, F. Modugno, Olive mill wastewaters: quantitation of the phenolic content and profiling of elenolic acid derivatives using HPLC-DAD and HPLC/MS2 with an embedded polar group stationary phase, Nat. Prod. Res. 33 (2019) 3171-3175, doi: https://doi.org/10.1080/14786419.2018.1522632.

17. J. Lu, W. Peng, Y. Lv, Y. Jiang, B. Xu, W. Zhang, J. Zhou, W. Dong, F. Xin, M. Jiang, Application of Cell Immobilization Technology in Microbial Cocultivation Systems for Biochemicals Production, Ind. Eng. Chem. Res. 59 (2020) 1702617034, doi: https://doi.org/10.1021/acs.iecr.0c01867.

18. J. Rodier, B. Legube, N. Merlet, L'analyse de I'eau, $9^{\text {th }}$ Ed., Dunod, Paris, 2009.

19. R. M. Lamuela-Raventós, Folin-Ciocalteu method for the measurement of total phenolic contentand antioxidant capacity, Meas. Antioxid. Act. Capacit. Recent Trends Appl. (2017) 107-115, doi: https://doi.org/10.1002/9781119135388. ch6.

20. N. Obara, N. Oki, M. Okai, M. Ishida, N. Urano, Development of a simple isolation method for yeast Saccharomyces cerevisiae with high fermentative activities from coastal waters, Act. from Coast. Waters 4 (2015) 71-76, doi: https:// doi.org/10.11425/sst.4.71.

21. S. Ntougias, F. Gaitis, P. Katsaris, S. Skoulika, N. Iliopoulos, G. I. Zervakis, The effects of olives harvest period and production year on olive mill wastewater properties - Evaluation of Pleurotus strains as bioindicators of the effluent's toxicity, Chemosphere 92 (2013) 399-405, doi: http//doi. org/10.1016/j.chemosphere.2013.01.033.
22. P. Dutournié, M. Jeguirim, B. Khiari, M.-L. M. L. Goddard, S. Jellali, Olive mill wastewater: From a pollutant to green fuels, agricultural water source, and bio-fertilizer. Part 2: Water recovery, Water 11 (2019) 768, doi: https://doi.org/10.3390/ w11040768.

23. M. El Yamani, E. H. Sakar, A. Boussakouran, N. Ghabbour, Y. Rharrabti, Physicochemical and microbiological characterization of olive mill wastewater (OMW) from different regions of northern Morocco, Environ. Technol. 41 (2020) 3081-3093, doi: https://doi.org/10.1080/09593330.2019.1 597926.

24. Y. Rharrabti, M. El Yamani, Olive Mill Wastewater: Treatment and Valorization Technologies, in C. Hussain (ed.), Handbook of Environmental Materials Management. Springer, Cham, 2018, pp. 1-28, doi: https://doi.org/10.1007/978-3319-58538-3_91-1.

25. R. Jarboui, M. Chtourou, C. Azri, N. Gharsallah, E. Ammar, Time-dependent evolution of olive mill wastewater sludge organic and inorganic components and resident microbiota in multi-pond evaporation system, Bioresource Technol. 101 (2010) 5749-5758, doi: https://doi.org/10.1016/j.biortech.2010.02.069.

26. K. Simyrdanis, N. Papadopoulos, P. Soupios, S. Kirkou, P. Tsourlos, Characterization and monitoring of subsurface contamination from Olive Oil Mills' waste waters using Electrical Resistivity Tomography, Sci. Total Environ. 637638 (2018) 991-1003, doi: https://doi.org/10.1016/j.scitotenv.2018.04.348.

27. Z. Kaleh, S. U. Geißen, Selective isolation of valuable biophenols from olive mill wastewater, J. Environ. Chem. Eng. 4 (2016) 373-384, doi: https://doi.org/10.1016/j. jece.2015.11.010.

28. W. Medawar, P. Strehaiano, M. L. Délia, Yeast growth: Lag phase modelling in alcoholic media, Food Microbiol. 20 (2003) 527-532, doi: http//doi.org/10.1016/S07400020(02)00170-3.

29. D. Sarris, S. Papanikolaou, Biotechnological production of ethanol: Biochemistry, processes and technologies, Eng. Life. Sci. 16 (2016) 307-329, doi: http//doi.org/10.1002/ elsc.201400199.

30. D. Zanichelli, F. Carloni, E. Hasanaj, N. D. Andrea, A. Filippini, L. Setti, Research Communications Production of Ethanol by an Integrated Valorization of Olive Oil Byproducts The Role of Phenolic Inhibition, Environ. Sci. Pollut. Res. Int 14 (2007) 5-6, doi: https://doi.org/10.1065/espr2006.06.316. 


\title{
SAŽETAK
}

\section{Proizvodnja bioetanola iz otpadnih voda prerade maslina primjenom imobiliziranih stanica}

\author{
Khadidja Ayadi, ${ }^{a^{*}}$ Malika Meziane, ${ }^{\mathrm{b}}$ Djawed Rouam, ${ }^{\mathrm{b}}$ \\ Mohammed Noureddine Bouziane ${ }^{\mathrm{i}}$ Khaled El-Miloudic
}

U ovom radu analizirane su fizikalno-kemijske i mikrobiološke karakteristike otpadnih voda tradicionalnih postrojenja za preradu maslinova ulja u Ennakhla-Chlefu u sjevernom Alžiru. Uzorci otpadne vode imali su slabu kiselost od $0.65 \% \mathrm{uz} \mathrm{pH}=4,88$ i električnu provodnost od $34 \mathrm{mS} \mathrm{cm}^{-1}$. Vrijednosti kemijske i biološke $\left(\mathrm{BPK}_{5}\right)$ potrošnje kisika kretale su se do 183 odnosno $7 \mathrm{gl}^{-1}$. Nadalje, uzorci su sadržavali 1,72 $\mathrm{gl}^{-1}$ ukupnih fenola. Preliminarna mikrobiološka analiza ukazala je na prisutnost raznih mikroorganizama, osobito bakterija mliječne kiseline i Enterococcus sp.

\section{Ključne riječi}

Otpadne vode prerade maslina, fizikalno-kemijski parametri, mikrobni sastav,

fermentacija imobiliziranih stanica, bioetanol

a Laboratoire Eau et Environnement, Faculté de Technologie, Université Hassiba Benbouali de Chlef, Alžir

b Laboratoire Bio-Ressources Naturelles,

Faculté des Sciences de la Nature et de la Vie, Université Hassiba Benbouali de Chlef, Alžir

c Laboratoire Physique Théorique et Physique des Matériaux, Faculté de Technologie,

Université Hassiba Benbouali de Chlef, Alžir
Izvorni znanstveni rad Prispjelo 13. ožujka 2021. Prihvaćeno 11. listopada 2021. 